\title{
Intraplate Strike-Slip Reactivation of the Sinnyeong Fault in the Cretaceous Gyeongsang Basin, Korea, Due to the Concentration of Later Compressional Stress
}

\author{
Youngbeom Cheon, Cheol Woo Song, Son Kap Lee, Jong-Sun Kim, Moon Son* \\ Department of Geological Sciences, Pusan National University, Busan, South Korea \\ Email: moonson@pusan.ac.kr
}

Received October 2013

\begin{abstract}
This study focuses on the geometry and kinematics of the Sinnyeong Fault which is the most conspicuous fault among the WNW-trending Gaeum Fault System in the Gyeongsang Basin, SE Korea. The fault is traced for over ca. $70 \mathrm{~km}$ and has a consistent WNW-trending strike with a nearly vertical dip. It has an asymmetric fault damage zone of several meters to several tens of meters in width and a several metersthick fault core. Its main movement is interpreted as sinistral-reverse oblique-slip or sinistral strike-slip under NE-SW compressional stress regime, although it could have experienced other faultings with different senses before/after this movement. Cylindrical folds, having the NW-trending fold axes of low-angle plunge, are only observed along the southern damage zone of the fault with a continuous narrow width of several tens of meters. It is thus interpreted that the formation of the folds and sinistral movement of the fault were almost contemporaneously generated due to the concentration of the regional NE-SW compressional stress along pre-existing WNW-trending faults or densely populated fracture zone in a relatively stable intraplate region.
\end{abstract}

Keywords: Sinnyeong Fault; Sinistral-Reverse Oblique-Slip; Compressional Stress; Pre-Existing Fault

\section{Introduction}

The Gyeongsang Basin, located in the eastern part of the Korean Peninsula, is a Cretaceous back-arc basin produced by the oblique subduction of the Proto-Pacific (Izanagi/Kula) plate underneath the Eurasia plate (Chough et al., 2000; Chough \& Sohn, 2010; Figure 1). It was filled by the Cretaceous-Paleogene non-marine sedimentary and igneous rocks. The fault systems in the basin are generally divided into two types, i.e. NNE-trending Yangsan Fault and WNW-trending Gaeum Fault systems, based on the attitudes (Figure 1). Their geometry and kinematics are potentially important for understanding the development history of the Gyeongsang Basin associated with tectonic evolution in East Asia during the Cretaceous to Cenozoic, because the basin-fills were cut by these fault systems (Figure 1). While various geological studies along the Yangsan Fault System have been carried out (Chang et al., 1990; Kim, 1992, 1993; Chang, 2002; Chang \& Chang, 1998; Cho et al., 2007, Choi et al., 2009; Kang \& Ryoo, 2009, etc.), detailed structural analyses of the Gaeum Fault System, including descriptive and kinematic analyses, are not performed although several geological mappings along the fault system were carried out (Chang et al., 1977, 1978, 1981; Won et al., 1980; Kim et al., 1981).

The aim of this study is to decipher the geometry and kinematics of the Sinnyeong Fault which is one of the most conspicuous strands comprising the Gaeum Fault System (Figure 1). By detailed field descriptions along the fault, various structural elements, such as slip data of various scale faults and shear fractures, attitudes of extensional fracture, and beddings of

\footnotetext{
${ }^{*}$ Corresponding author.
}

adjacent sedimentary rocks, were measured and analyzed to determine the nature of deformation along the fault and to examine the causative paleostress field.

\section{Geological Background}

The Gyeongsang Basin can be tectonically divided into three subbasins, i.e. Yeongyang, Uiseong, and Miryang subbasins from north to south (Chang, 1975; Figure 1). The Gaeum Fault System is located in the Uiseong Subbasin which was filled by non-marine sedimentary, volcanic, and plutonic rocks. The sedimentary rocks are divided into the Sindong and Hayang groups which are intruded and/or overlain by acidic-intermediate volcanic complex, named Yucheon Group. Afterwards, the Bulguksa granites, containing acidic and intermediate intrusive rocks, immediately intruded the earlier strata (Chang et al., 1977, 1981; Won et al., 1980; Kim et al., 1981).

The WNW-trending Gaeum Fault System consists of the Hwanghaksan, Uiseong, Geumcheon, Jarak, Gaeum, Gunwi, Ubo, Sinnyeong, and Palgongsan faults from north to south and cuts the above-mentioned sedimentary, volcanic, and intrusive rocks as well as several cauldrons with sinistral offset (Chang et al., 1977, 1981; Won et al., 1980; Kim et al., 1981; Choi et al., 2004). The geological map of the Daeyul Sheet $(1 / 50,000)$ reported that the Sinnyeong Fault is a sinistral strike-slip fault (Kim et al., 1981). Other 1/50,000 geological maps (the Gusandong, Sinnyeong, and Gunwi Sheets) interpreted that the intrusive rocks intruded along the pre-existing WNW-trending faults, afterwards these faults reacted as sinistral strike-slip faults, based on the sub-parallel trends of the intrusions and the faults (Chang et al., 1977, 1981; Won et al., 1980). Chang \& 


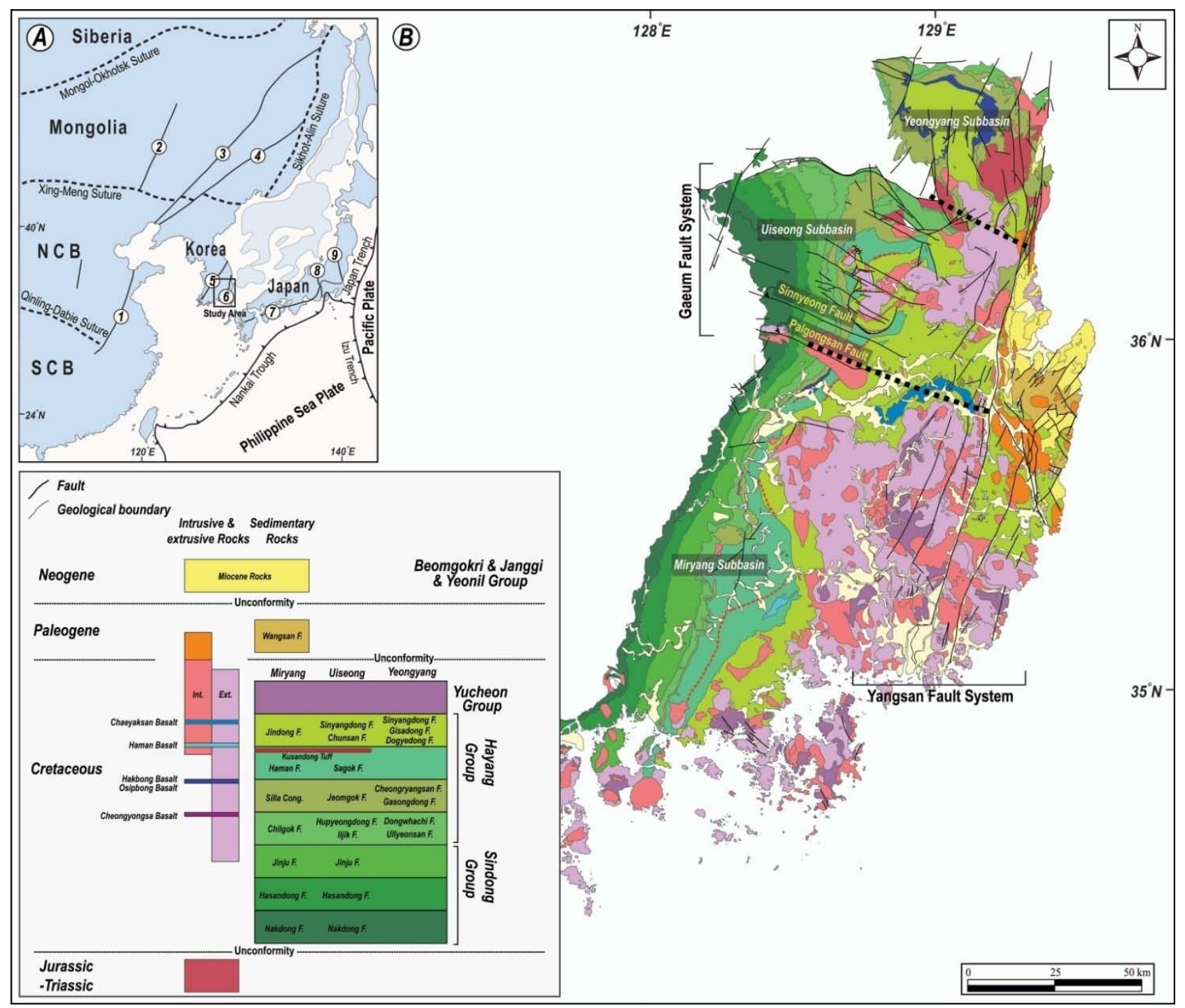

Figure 1.

(A) Tectonic outline of the eastern Eurasian margin (modified after Xu et al., 1987; Ren et al., 2002; Itoh et al., 2006), 1. Tan-Lu Fault, 2. Nenjiang Fault, 3. Yilan-Yitong Fault Zone, 4. Fushan-Mishan Fault, 5. South Korean Tectonic Line, 6. Yangsan Fault System, 7. Median Tectonic Line, 8. Itoigawa-Shizuoka Tectonic Line, 9. Tanakura Tectonic Line. (B) Simplified geological map (modified from Hwang et al., 1996; Kim et al., 1998; Choi et al., 2002) and key beds (modified from Jeong et al., 2005; Jeon \& Sohn, 2008; Hwang \& Woo, 2009) of the Gyeongsang Basin. Stratigraphic correlation is reconstructed from Chang et al. (2003), Chough \& Sohn (2010), and Kang \& Paik (2013).

Park (1997) and Chang et al. (1997) also suggested that the Palgongsan Fault acted as a syn-depositional fault during the deposition of the lower strata of the Hayang Group, afterwards acted as a conduit of the Palgongsan Granite, and finally reacted as sinistral strike-slip fault. Based on topographic texture analysis, Choi et al. (2004) interpreted that dextral movement along the Sinnyeong Fault occurred during the Campanian to Eocene, afterwards the fault was reactivated as a sinistral strike-slip faults together with nearby WNW-trending faults during the Pliocene. They also argued that the NNE-trending Yangsan Fault was cut and left-laterally displaced by them. On the other hand, Lee \& Hwang (1997) suggested that the sinistral strike-slip movement of the Gaeum Fault System and associated NS-trending open folding were produced under EW compressive stress field which was followed by NE-SW compressive stress field resulting in dextral strike-slip faulting of the Yangsan Fault System.

\section{Structures Characteristics}

\section{Field Descriptions along the Fault}

The Sinnyeong Fault, observed in the Site-1, has a nearly vertical dip with a strike of $N 70^{\circ} \mathrm{W}$, and cuts the sandstone and siltstone of the Hayang Group. An about 6 m-thick fault core is composed of incohesive fault breccias and gouges, which anastomose and link up with each other (Figure 2(A)). They also show a NW-trending rearrangement (foliation in S-C fabric) indicating sinistral movement of the fault (Figures 2(B), (C)). Sinistral-reverse oblique-slip senses with rakes less than $20^{\circ}$ are observed on the main fault surfaces. In the damage zone, a lot of ENE-trending shear fractures having sinistral sense (Figure 2(D)) and NE-trending extensional fractures showing comb 

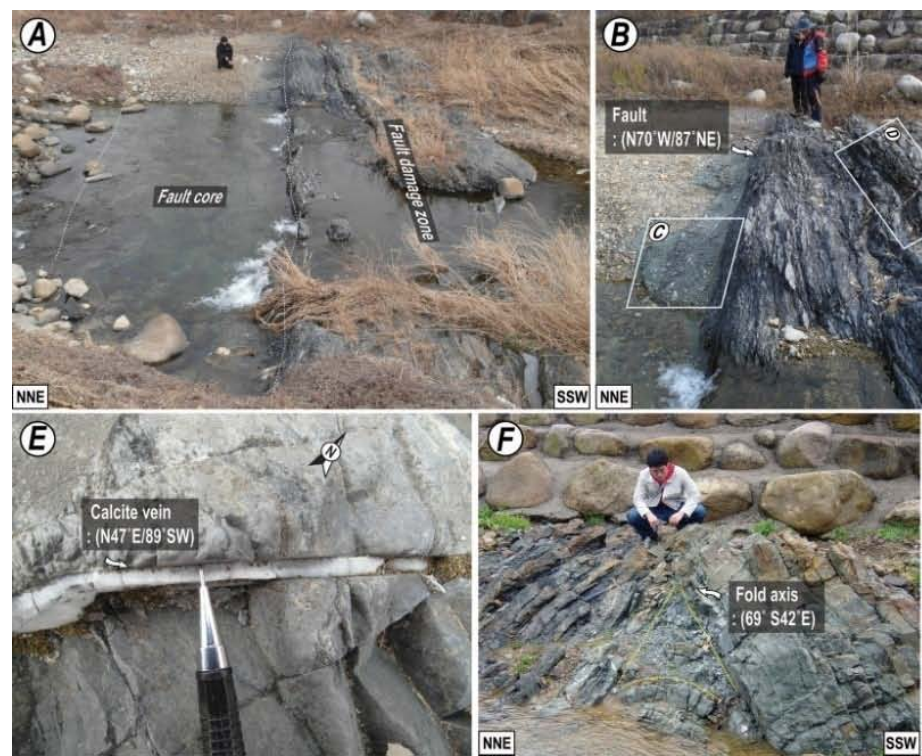
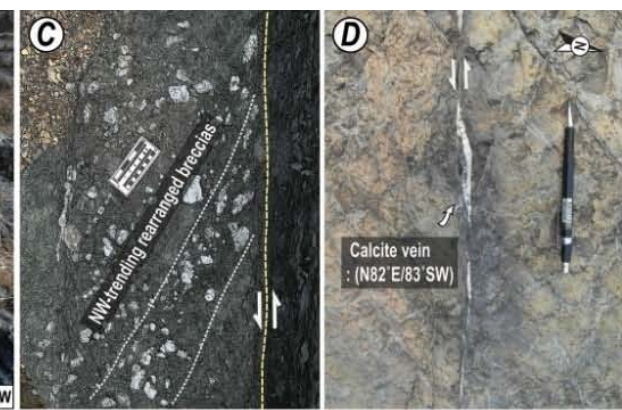

(G)

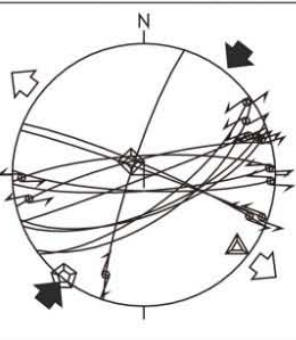

(H)

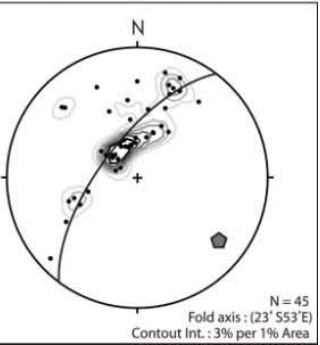

Figure 2.

Outcrop photographs of the Sinnyeong Fault. (A) A photograph of an exposure of the fault showing a WNW-trending fault zone. (B) Pervasively crushed rocks in a fault core and strata having vertical dip angles in a fault damage zone. (C) NW-trending rearrangement (foliation in S-C fabrics) in a fault core indicating sinistral movement of the fault. (D) ENE-trending shear fractures showing sinistral sense. (E) A NE-trending extensional fracture showing comb structure. (F) A NW-trending fold observed in the southern damage zone of the fault. (G) Slip data in the fault zone (lower-hemisphere, equal-area projections). Convergent and divergent arrow heads represent contraction $\left(\sigma_{H \max }\right)$ and horizontal stretching $\left(\sigma_{\mathrm{Hmin}}\right)$ direction, respectively (Choi, 1995). (H) Fold axes estimated from best-fitting $\pi$-circles of various attitudes of fold limbs.

structures (Figure 2(E)) are frequently observed. Meanwhile, the strike of sedimentary strata tends to be more parallel to the strike of the fault and the dip becomes more vertical closer to the fault core, but these features are remarkably dominant in the southern block of the fault. NW-trending folds having several meters in width are also observed in about 60 m-thick fault damage zone of the southern block (Figure 2(F)).

The main fault, observed in the Site-2, strikes $N 87^{\circ} \mathrm{W}$ and dips $72^{\circ} \mathrm{SW}$ on outcrop and has about $1 \mathrm{~m}$-thick fault core consisting of incohesive fault gouges and breccias. Slickenlines indicating sinistral-reverse oblique-slip sense are observed on the main fault surface. Meanwhile, it is notable that the bed attitudes adjacent to the main fault are markedly discriminable in the northern and southern blocks of the fault. In details, the bed attitudes in the northern block mainly define a homoclinal structure dipping toward the NW with $10^{\circ}-15^{\circ}$ angles, whereas those in the southern blocks define a few meters to centimeters-width folds having constantly northwestward-plunging fold axes with about $20^{\circ}$ angles.

\section{Cylindrical Folds along the Faults}

The bed attitudes of the sedimentary rocks in the Uiseong Subbasin generally define a homoclinal structure dipping toward east or east-southeast, although this pattern is complicated by intrabasinal faulting and formation of cauldrons.

The various scale cylindrical folds observed along the southern damage zone of the Sinnyeong Fault thus can be attributed to (1) the regional stress causing movement of the fault or (2) the dragging associated with the faulting. The geometry of folds produced by regional stress is, however, distinguishable from that of drag folds, because the folds mostly show a cylindrical geometry and similar trends of the axes. The fold axes thus can be used to reconstruct the paleostress field and to determine the direction of crustal contraction (Jonk \& Biermann, 2002; Kim et al., 2008; etc.). On the other hand, the drag folds are results of a distortion of bedding or other layering, resulting from shearing of rock bodies (Davis \& Reynolds, 1984; Twiss \& Moores, 2007; etc.), and can be an important role for inferring the movement sense of faulting (Becker, 1995; Choi et al., 2004). Geometry of drag fold is significantly affected by the movement sense of fault and pressure-temperature conditions. In other words, dip-slip faulting generally forms a cylindrical drag fold with the slip direction roughly perpendicular to the fold axis, whereas oblique-slip and strike-slip faulting can be easy to form a conical fold excepting one formed by only flexural slip without volume redistribution (Becker, 1995).

The features of the observed folds along the Sinnyeong Fault are as follows. (1) Cylindrical geometry, (2) tens of meters to several centimeters in width, (3) various tightness, gentle to tight folds, (4) NW-trending fold axes with low-angle plunge (Figure 2(H)), and (5) concentration of their distribution in the southern damage zone of the fault with a continuous narrow width of several tens of meters. These structural characteristics imply that the folding was intimately related with regional compressional stress rather than dragging or distortion by faulting.

\section{Reconstruction of Paleostress Fields}

A few centimeters to ten meters-width cylindrical folds having various interlimb angles are intensively distributed in the southern damage zone of the Sinnyeong Fault. We reconstructed the fold axis estimated from best-fitting $\pi$-circles of various attitudes of fold limbs in the Site-1. The fold axis trends $\mathrm{S} 53^{\circ} \mathrm{E}$ and plunges $23^{\circ}$ southeastward (Figure 2(H)), which is approximately the same attitude to those of minor folds measured in the field. 
A number of slip data from minor faults observed close to the Sinnyeong Fault were measured and analyzed to reconstruct the paleostress fields. The results show the sinistral movement of the fault was produced under a NE-SW compressional stress $\left(\mathrm{R}^{\prime}=1.744\right.$; Delvaux et al., 1997; Figure 2(G)). Several NEtrending calcite veins, observed in the Site-1, also show comb structures growing in NW-SE direction that is commonly controlled by the instantaneous stretching axis. It is thus interpreted that the formation of the NE-trending calcite veins was nearly coeval with the sinistral movement of the Sinnyeong Fault under the NE-SW compressional stress regime.

These kinematic indicators show that the sinistral movement of the Sinnyeong Fault was produced under the NE-SW compressional stress accompanying the subsidiary minor contractional and extensional structures in the southern fault damage zone of the fault.

\section{Discussion}

\section{Geometry and Kinematics of the Sinnyeong Fault}

The lineament of the Sinnyeong Fault, strikingly recognized in the satellite and DEM images, is continuously traced with $\mathrm{N} 70^{\circ} \mathrm{W}$ trend. The strikes of the fault measured in outcrops, however, range from $\mathrm{N} 49^{\circ}$ to $87^{\circ} \mathrm{W}$ with subvertical dips toward north or south. The damage zone of several meters to several tens of meters in width and a several meters-thick fault core are observed along the fault. It is notable that the southern block of the fault is more deformed than the northern block in most observed outcrops.

Most of the kinematic indicators suggest sinistral-reverse oblique-slip or sinistral strike-slip movements along the WNWtrending faults associated with partial compression, although dip-slip and dextral-slip senses are occasionally observed. Because the slip direction and sense determined by kinematic indicator such as slickenline, crystal fiber, and ridge and groove structure on the fault surfaces generally indicate the last or strongest movement of faults (Becker, 1995), the sinistral movement of the faults is interpreted to represent the last or strongest displacement of the faults.

\section{Contractional Structures and Fault Reactivation}

The NW-trending folds distributed only along and adjacent to the Sinnyeong Fault, compressional component observed on the main fault, and NE-SW-directed maximum horizontal stress reconstructed from the fault slip data indicate collectively that the formation of the folds was contemporaneous with or immediately before the sinistral movement of the fault. It is notable that the contractional structures in the host rocks are significantly concentrated within the continuously narrow zone of several tens of meters along the fault, implying that the sinistral movement of the fault and formation of the contractional structures resulted from the reactivation of suitably oriented preexisting fault and/or weakened zone (Letouzey et al., 1990; Cunningham, 2007; Mann, 2007; Cunningham \& Mann, 2007).

The sinistral reactivation of pre-existing fault and/or weakened zone is also supported by the following evidences. Firstly, multiple slip senses including normal-slip are occasionally observed on the main fault surfaces, although the sinistralreverse oblique-slip is most dominant. Secondly, several previous studies suggested that the initial movement of the WNWtrending faults was coeval with the deposition of the lower strata of the Hayang Group and then they played a role as conduits of the granitic magma (Chang et al., 1977, 1981; Won et al., 1980; Chang \& Park, 1997; Chang et al., 1997). Thirdly, Chang (1975) interpreted that Miryang and Uiseong subbasins was tectonically divided by the Palgongsan Fault (or Palgongsan Granite), based on the abrupt change of sedimentary facies across the fault.

Reactivation of pre-existing faults or alternatively new failures depend on the geometry of pre-existing faults, state of stress, physical properties of fault rocks (cohesion, friction, etc.), mineralogic/chemical weakening of fault rocks, fluid pressure conditions, and so on (Sibson, 1985; Letouzey et al., 1990; Holdsworth et al., 1997). Movement sense of the reactivation faults was crucially controlled by the geometry of the pre-existing fault in relation with the regional stress field. In other words, some pre-existing faults having high angles could not be easily reactivated or could be reactivated as strike-slip faults rather than reverse faults, when the strikes of the faults are nearly perpendicular or oblique to the orientations of maximum horizontal stress (Davis \& Reynolds, 1984; Letouzey et al., 1990). In case of the Sinnyeong Fault, the angle between the direction of maximum horizontal stress and strike of the fault is about $70^{\circ}-80^{\circ}$ and the dips of the fault are subvertical, which also supports that the Sinnyeong Fault has been reactivated as a sinistral fault under the NE-SW compressional stress.

In short, it is interpreted that the sinistral faulting of the Sinnyeong Fault was produced by the concentration of the regional compressional stress along the pre-existing WNW-trending faults or densely populated fracture zone within a relatively stable intraplate region (Figure 3).

\section{Conclusion}

Detailed field descriptions along the fault and kinematic analysis were carried out in order to determine the geometry and kinematics of the Sinnyeong Fault. The results are as follows.

(1) The Sinnyeong Fault is traced for over $70 \mathrm{~km}$ and has a consistent WNW-trending strike with nearly vertical dips. It has an asymmetric fault damage zone of several meters to several tens of meters in width and a several meters-thick fault core consisting of incohesive fault gouges and breccias. Based on the lateral offset of ca. $1 \mathrm{~km}$, slip markers on fault plane, and rearranged fault gouges and breccias (S-C fabric), its main movement is interpreted as sinistral-reverse oblique-slip or sinistral strike-slip.

(2) Associated minor structures observed in the fault zone, such as shear and extensional fractures and cylindrical folds, also indicate that the main movement of the fault was sinistralreverse oblique-slip produced under the NE-SW compressional stress regime, although it could have experienced other faultings with different senses before/after this movement. Bed attitudes of sedimentary rocks within the fault damage zone tend to be more parallel to the fault attitude closer to the fault core and this feature is observed much more obviously in the southern block of the fault.

(3) NW-trending cylindrical folds, produced by the regional compressional stress, are also exclusively distributed along the southern damage zone of the fault with a continuous narrow width of several tens of meters, indicating that the formation of folds is contemporaneous with or immediately before the sinistral movement of the fault under the NE-SW compressional 


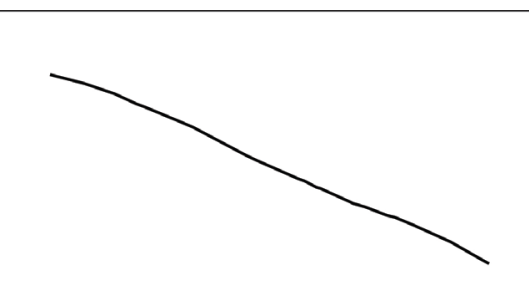

(A)

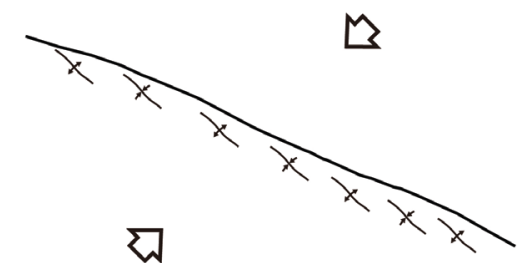

(B)

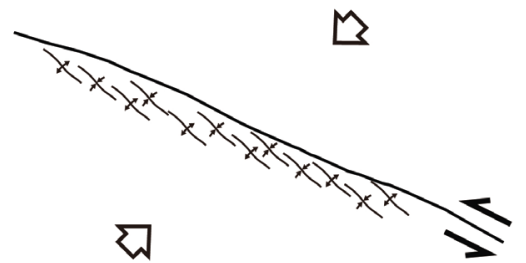

(C)

Figure 3.

Schematic diagrams illustrating a sinistral reactivation of the Sinnyeong Fault. (A) A WNW-directed pre-existing fault; (B) Formation of folds along the pre-existing fault or dense fracture due to concentration of regional NE-SW compressional stress; (C) Sinistral reactivation of the fault under progressive compressional stress.

stress regime. It is thus interpreted that the sinistral movement of the Sinnyeong Fault was produced by the concentration of regional compressional stress along pre-existing WNW-trending faults or dense fractures within a relatively stable intraplate region.

\section{Acknowledgements}

This work was supported by the Korea CCS R\&D Center (KCRC) grant funded by the Korea government (Ministry of Science, ICT \& Future Planning) (No. 2013M1A8A1035887).

\section{REFERENCES}

Becker, A. (1995). Conical drag folds as kinematic indicators for strike-slip fault motion. Journal of Structural Geology, 17, 14971506. http://dx.doi.org/10.1016/0191-8141(95)00057-K

Chang, K. H. (1975). Cretaceous stratigraphy of southeast Korea. Journal of the Geological Society of Korea, 11, 1-23.

Chang, K. H., \& Park, S. O. (1997). Aspects of tectonics and volcanism recorded in Cretaceous medial Kyongsang Basin, SE Korea. Economic and Environmental Geology, 30, 143-151 (in Korean with English Abstract).

Chang, K. H., Park, H. I., Ko, I. S., \& Kim, H. M. (1977). 1: 50,000 geological map of Korea: The Gusandong sheet (25 p). Daejeon: KIGAM.

Chang, K. H., Park, S. O., \& Kim, H.-S. (1997). Cretaceous stratigraphy and geologic history of medial Kyongsang Basin: Tectonics and volcanism. Geosciences Journal, 1, 2-9.

http://dx.doi.org/10.1007/BF02910444

Chang, K. H., Park, H. I., Ko, I. S., \& Kim, H. M. (1981) 1: 50,000 geological map of Korea: The Gunwi sheet (25 p). Daejeon: KIGAM.

Chang, K. H., Woo, B. G., Lee, J. H., Park, S. O., \& Yao, A. (1990). Cretaceous and Early Cenozoic stratigraphy and history of eastern Kyongsang Basin, S. Korea. Journal of the Geological Society of Korea, 26, 471-487.

Chang, K. H., Koh, I. S., Park, H. I., Chi, J. M., \& Kim, H. M. (1978). 1: 50,000 geological map of Korea: The Cheonji sheet (20 p). Daejeon: KIGAM.

Cunningham, D. (2007). Structural and topographic characteristics of restraining bend mountain ranges of the Altai, Gobi Altai and easternmost Tien Shan. In W. D. Cunningham, \& P. Mann (Eds.), Tectonics of strike-slip restraining and releasing bends (pp. 219-237). London: Geological Society, Special Publications. http://dx.doi.org/10.1144/SP290.7

Chang, K.-H., Suzukib, K., Parka, S.-O., Ishida, K., \& Uno, K. (2003). Recent advances in the Cretaceous stratigraphy of Korea. Journal of Asian Earth Sciences, 21, 937-948.

http://dx.doi.org/10.1016/S1367-9120(02)00142-6

Chang, C. J., \& Chang, T. W. (1998). Movement history of the Yangsan fault based on Paleostress analysis. The Journal of Engineering
Geology, 8, 35-49 (in Korean with English Abstract).

Cho, H., Son, M., \& Kim, I.-S. (2007). Anisotropy of magnetic susceptibility (AMS) of the granitic rocks in the eastern region of the Yangsan fault. Economic and Environmental Geology, 40, 171-189 (in Korean with English Abstract).

Choi, J.-H., Yang, S.-J., \& Kim, Y.-S. (2009). Fault zone classification and structural characteristics of the southern Yangsan fault in the Sangcheon-ri area, SE Korea. Journal of the Geological Society of Korea, 45, 9-28 (in Korean with English Abstract).

Choi, P. Y. (1995). Aspects of stress inversion methods in fault tectonic analysis. Annales Tectonicae, 9, 22-38.

Choi, P. Y., Lee, S. R., Ko, I.-S., \& An, G.-O. (2004). Movement history of the Gaeum fault system. In Y. S. Lee, Y. H. Kihm, P. Y. Choi, A. Reedman, S.-Y. Kim, I.-J. Kim, S. Lee, H.-J. Shin, \& D. Shin, (Eds.), Cenozoic stratigraphy and tectonics of Korea (pp. 211-228). The 3rd and 4th Symposiums on the Geology of Korea, Special Publication No. 2. Korea Institute of Geoscience and Mineral Resources.

Choi, P. Y., Choi, H. I., Hwang, J. H., Kee, W.-S., Koh, H. J., Kim, Y. B., Lee, B. J., Song, K. Y., Kim, J. C., \& Choi, Y. S. (2002). 1: 250,000 geological map of Korea: The Mokpo and Yeosu sheets (48 p). Daejeon: KIGAM.

Chough, S. K., Kwon, S.-T., Ree, J.-H., \& Choi, D. K. (2000). Tectonic and sedimentary evolution of the Korean peninsula: A review and new view. Earth-Science Reviews, 52, 175-235. http://dx.doi.org/10.1016/S0012-8252(00)00029-5

Chough, S. K., \& Sohn, Y. K. (2010). Tectonic and sedimentary evolution of a Cretaceous continental arc-backarc system in the Korean peninsula: New view. Earth-Science Reviews, 101, 225-249. http://dx.doi.org/10.1016/j.earscirev.2010.05.004

Cunningham, W. D., \& Mann, P. (2007). Tectonics of strike-slip restraining and releasing bends. In W. D. Cunningham, \& P. Mann (Eds.), Tectonics of strike-slip restraining and releasing bends (pp. 1-12). London: Geological Society, Special Publications. http://dx.doi.org/10.1144/SP290.1

Davis, G. H., \& Reynolds, S. J., (1984). Structural geology of rocks and regions (2nd ed., 776 p). New York: John Wiley \& Sons, Inc.

Delvaux, D., Moeys, R., Stapel, G., Petit, C., Levi, K., Miroshnichenko, A., Ruzhich, V., \& San'kov, V. (1997). Paleostress reconstructions and geodynamics of the Baikal region, Central Asia, Part 2. Cenozoic rifting. Tectonophysics, 282, 1-38.

http://dx.doi.org/10.1016/S0040-1951(97)00210-2

Hwang, J. H., Kim, D. H., Cho, D. R., \& Song, K. Y. (1996). 1: 250,000 geological map of Korea: The Andong sheet (63 p). Daejeon: KIGAM.

Hwang, S. K., \& Woo, B. G. (2009) Role of the cheongryangsan conglomerate and the osipbong basalt in classifying stratigraphy of the Hayang Group, Yeongyang Subbasin. Journal of Petrology of Society of Korea, 18, 181-194 (in Korean with English Abstract).

Holdsworth, R. E., Butler, C. A., \& Roberts, A. M. (1997). The recognition of reactivation during continental deformation. Journal of the Geological Society, London, 154, 73-78. http://dx.doi.org/10.1144/gsjgs.154.1.0073

Itoh, Y., Uno, K., \& Arato, H. (2006). Seismic evidence of divergent rifting and subsequent deformation in the southern Japan Sea, and a 
Cenozoic tectonic synthesis of the eastern Eurasian margin. Journal of Asian Earth Science, 27, 933-943.

http://dx.doi.org/10.1016/j.jseaes.2005.09.008

Jeon, Y. M., \& Sohn, Y. K. (2008). Characteristics, emplacement processes, and stratigraphic implications of the basalts intercalated in the Hayang Group, Cretaceous Gyeongsang Basin, SE Korea. Journal of the Geological Society of Korea, 44, 707-727 (in Korean with English Abstract).

Jeong, J. O., Jeon, Y. M., \& Sohn, Y. K. (2005). Petrography and modal compositional variations of the Cretaceous Kusandong Tuff, Korea. Journal of the Geological Society of Korea, 41, 73-90 (in Korean with English Abstract).

Jonk, R., \& Biermann, C. (2002). Deformation in Neogene sediments of the Sorbas and Vera Basins (SE Spain): Constraints on simpleshear deformation and rigid body rotation along major strike-slip faults. Journal of Structural Geology, 24, 963-977. http://dx.doi.org/10.1016/S0191-8141(01)00107-9

Kang, H.-C., \& Paik, I. S. (2013). Review on the geological ages of the formations in the Gyeongsang Basin, Korea. Journal of the Geological Society of Korea, 49, 17-29 (in Korean with English Abstract).

Kang, J.-H., \& Ryoo, C.-R. (2009). The movement history of the southern part of the Yangsan Fault Zone interpreted from the geometric and kinematic characteristics of the Sinheung Fault, Eonyang, Gyeongsang Basin, Korea. Journal of the Petrological Society of Korea, 1, 19-30 (in Korean with English Abstract).

Kim, B. K., Cheong, C. H., Kim, S. J., \& Yang, S. Y. (1981). 1: 50,000 geological map of Korea: The Daeyul sheet (29 p). Daejeon: KIGAM.

Kim, D. H., Hwang, J. H., Park, K. H., \& Song, K. Y. (1998). 1: 250,000 geological Map of Korea: The Pusan sheet (36 p). Daejeon: KIGAM.

Kim, H., Song, C.-W., Kim, J.-S., Son, M., \& Kim, I.-S. (2008). Tertiary geological structures and deformation history of the Southern Tsushima Island, Japan. Journal of the Geological Society of Korea, 44, 175-198 (in Korean with English Abstract).

Kim, I.-S. (1992). Origin of tectonic evolution of the East Sea (Sea of Japan) and the Yangsan fault system: A new synthetic interpretation. Journal of the Geological Society of Korea, 28, 84-109 (in Korean with English Abstract).

Kim, J.-Y. (1993). Fault system and fracture zone of the Yangsan fault. Journal of Korean Earth Science Society, 14, 281-299 (in Korean with English Abstract).

Lee, B. J., \& Hwang, J. H. (1997). Relationship between the Kaum fault and the Yangsan fault at the northeastern part of the Cretaceous Kyongsang Basin, Korea. Journal of the Geological Society of Korea, 33, 1-8 (in Korean with English Abstract).

Letouzey, J., Werner, P., \& Marty, A. (1990). Fault reactivation and structural inversion. Backarc and intraplate compressive deformations. Example of the eastern Sunsa shelf (Indonesia). Tectonophysics, 183, 341-362. http://dx.doi.org/10.1016/0040-1951(90)90425-8

Mann, P. (2007). Global catalogue, classification and tectonic origins of restraining- and releasing bends on active and ancient strike-slip fault systems. In W. D. Cunningham, \& P. Mann (Eds.), Tectonics of strikeslip restraining and releasing bends (pp. 13-142). London: Geological Society, Special Publications. http://dx.doi.org/10.1144/SP290.2

Ren, J., Tamaki, K., Li, S., \& Junxia, Z. (2002). Late Mesozoic and Cenozoic rifting and its dynamic setting in Eastern China and adjacent areas. Tectonophysics, 344, 175-205. http://dx.doi.org/10.1016/S0040-1951(01)00271-2

Rhee, C. W., Jo, H. R., \& Chough, S. K., (1998). An allostratigraphic approach to a non-marine basin: The north-western part of Cretaceous Kyongsang Basin, SE Korea. Sedimentology, 45, 449-472. http://dx.doi.org/10.1046/j.1365-3091.1998.00180.x

Won, C. K., Yoon, S., \& So, C. S. (1980). 1: 50,000 geological map of Korea: The Sinnyeong sheet (21 p). Daejeon: KIGAM.

Sibson, R. H. (1985) A note on fault reactivation. Journal of Structural Geology, 7, 751-754. http://dx.doi.org/10.1016/0191-8141(85)90150-6

Twiss, R. J., \& Moores, E. M. (2007). Structural geology (2nd ed., 736 p). New York: W. H. Freeman and Company.

Xu, J. W., Zhu, G., Tong, W. X., Cui, K. R., \& Lin, Q. (1987). Formation and evolution of the Tancheong-Lujiang wrench fault system: A major shear system to the northwest of the Pacific Ocean. Tectonophysics, 134, 273-310.

http://dx.doi.org/10.1016/0040-1951(87)90342-8 